\title{
Anthropology between Man and Architecture
}

\author{
Borut Juvanec* \\ Institute of Vernacular Architecture, Ljubljana University, Europe
}

Submission: May 03, 2019; Published: May 20, 2019

*Corresponding author: Borut Juvanec, Institute of Vernacular Architecture, Ljubljana University, Prijateljeva 11, 1 Ljubljana Slovenia, Europe

Abstract

The human body is composed of certain elements but all the components and the body itself are built in rigorous order. Not only in their number, but in its dimensions and other characteristics. Architecture has the same elements and, as a technical discipline, it is more rigorous. Vernacular architecture, the product of simple, unschooled people, has much stricter order, not as a constraint but for simplification and to avoid mistakes. Both the human body and vernacular architecture are simple as a totality but complicated in details, for the best function. The methodology of the article consists of a technical survey of human body, its dimensions and possibilities in practice. Practice is extremely complicated because of differences in men's heights.

Theory is based on mathematical expressions that are exact. Simple geometrical objects helped a lot: the trunk of a tree is circular, but a usable beam must be square - the common relation is the square root of two. Today we use mathematics, in the past simple but exact geometry was used. The result is a harmonising of interests. The best solution is nature itself: all its elements are built in accordance. Only harmonious composition can be beautiful. The conclusion is a very short recognition: beauty is the final goal of art and, if art is the ultimate conception in our built world, also in architecture.

Keywords: Nature; Anthropology; Architecture; Relation; Dimension; Harmony

\section{Introduction}

The human body is composed of certain elements, but all the components and the body itself are built to a rigorous order. Not only in their number, but in their dimensions and other characteristics. Architecture has the same elements and, as a technical discipline, it is more rigorous. Vernacular architecture, as a product of simple, unschooled people, has much stricter order, not as a constraint, but for simplification and to avoid mistakes. Both the human body and vernacular architecture are simple in totality but complicated in detail, for the best function. Primeval man understood that order is very important. Order between quanta: in length, cross section and volume. He formulated the first measures by himself: finger (inch), fist, elbow (cubit), foot, step, reach. The problem was that no one foot or elbow were the same [1]. The surface area in use in czarist Russia seems unlikely: 'utro' or 'morning' in English. This was the area that could be walked in one morning - but no step, speed or length of the morning was defined. It is no wonder that this 'utro' is no longer in use.

Precision is very important. This has been understood by some prominent scientists in history.

a. Pythagoras: Everything can be defined by numbers. b. Karl Marx: Science will be perfect only with the use of mathematics.

c. Le Corbusier: The project net is a guarantee against the self-will of individuals.

d. Walter Gropius: Use of the golden section, modules in old Greece, triangulation in Gothic, are proof of the use of optical keys in the past [2].

Today's measurements use the decimal system, for simplification. One meter is the $40,000,000$ st part of the meridian arc length [3]. The decimal system is very simple, and the old systems were extremely complicated. Leigemann wrote how the ancient stadion fit into the ancient foot system, with a length of 600 feet, although Ptolemny used station as a length of 700 stadia [3]. More interesting is the use of measures in Egyptian pyramids, with a length of baseline of 440 Cheops cubits. 'The units of length of the pyramid builders were abandoned in Egypt during the middle dynasty, a new royal cubit was introduced then, which is the Egyptian Royal cubit with 2 gudea - units of $529.1 \mathrm{~mm}$. There is one famous Greek exception: the stadium in Olympia was built very precisely according to 600 Herakles 'pous' [3]. No measurement system is perfect. 


\section{Methodology and Problematics}

The methodology of the article consists of a technical survey of the human body, its dimensions, reach and possibilities and its application in the measurement system. Man's likeness can be understood (every individual sees firstly himself), and this is the main problem: no two people are alike. Formal dimensions such as finger, fist, palm, foot, step or reach of a man depend on one man only. It is thus no wonder an extremely large number of different dimensions for the foot or elbow, the cubit, were used. The metric system, with decimal numbers, is technically the best solution, but it suppresses human harmony, closeness to man. Practice is extremely complicated because of difference in men's heights. The most important man in a monarchy was the king, and formal dimensions were often adapted to him. Some emperors were tall, and some weren't; they were 'human'. Dimensions were different but the relations between them were fixed. Only relations between quanta can be used. And relations are fixed. The human measurements system is close to the human body. An individual likes his own body, he knows it: why not use it for the simplification of his work? Of course, there are exceptions, because of the different lengths of some elements (Figure 1).

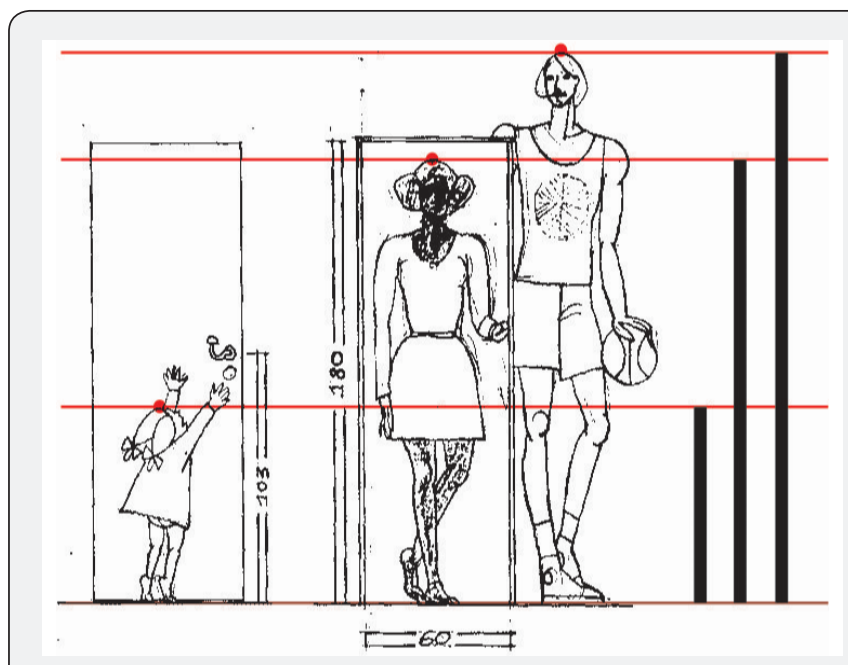

Figure 1: The door-handle is too high for a child, while the same door is too small for a basketball player. Exceptions exist everywhere (drawing Marjan Amalietti 1980).

Anthropomorphic measures are close to a man's body, from the finger (some millimetres) to the reach of a man, more than two metres in length. The English system uses inch, palm, span, foot, cubit, yard, fathom, all dimensions that are close to the body. A composition with anthropometric measurements can be harmonized from details to the whole (Figure 2). There are three important problems with anthropometric lengths:

a. Increasing basic measures,

b. Source of the anthropometric measures and

c. Complexity of mathematical expressions.

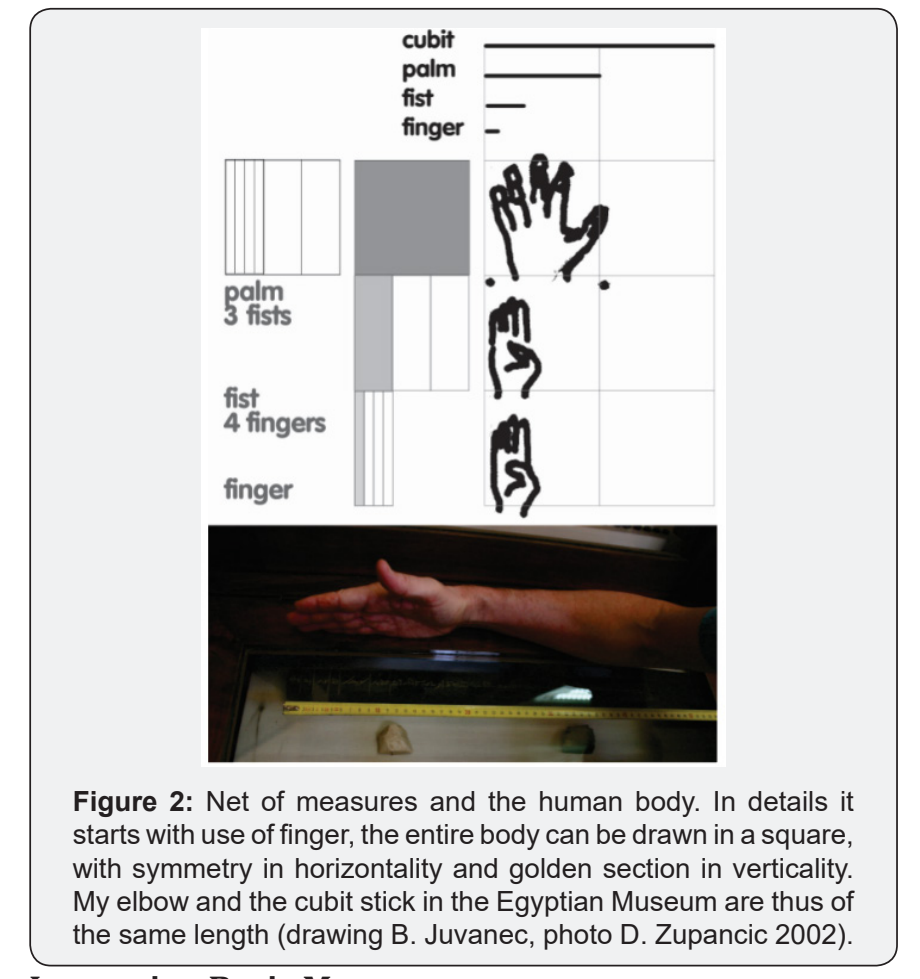

\section{Increasing Basic Measures}

The metric (decimal) system is mostly in use today, but the following lengths can also be found in some countries. The complexity of the system can be seen here:

1 foot = 12 inches; 1 yard = 3 feet; 1 rod, pole = $51 / 2$ yards etc); 40 rods = 1 furlong; 8 furlongs = 1 statute mile). It is hard to understand, even harder for addition.

\section{Source of Anthropometric Measures}

The not understood and complicated system with fingers, feet, steps is accommodated to man: but to which man and to a man in which time? Medieval man was shorter than my father, my father was shorter than me, and I am shorter than my son, at least. One foot seems to be a very simple and suitable measure. Is it really? There is not just one length of a foot (German: Schuh, Slovene: cevelj) - the lengths are as follows:

Gewoenlichen Schuh Germany

$\mathrm{cm}$

Dezimalschuh Germany

Greek, Roman foot (pous, pes)

English foot

Vienna foot

Ljubljana foot (Slovene: cevelj)

Venice foot

Schuh, Germany

(Hippel,W 1994:5) 


\section{Global Journal of Archaeology \& Anthropology}

\section{Complexity of Mathematical Expressions}

The golden section cannot be written with the use of simple numbers: it is a very sophisticated proportion, but hard to express with numbers. It can be understood; it cannot be defined without knowledge of mathematics. The facts are as follows:

The diagonal of a square according to Pythagoras is the square root of two, if the baseline is equal to one. The diagonal of two squares is the square root of five. The golden section can be derived on the length of two squares (Figure 3) (with lengths equal to two, and the diagonal equal to the square root of five). The problem is using this system in vernacular architecture, which was created by unschooled, simple masters. They saw their own bodies and they used the system of golden section (Figure 4). It was used not only in history, but also in recent times. Women's fashion in a skirt uses 'new' expressions such as 'mini, midi and maxi' - even the automobile industry uses them (Figure 5). Practical use of complex systems is surprisingly simple.

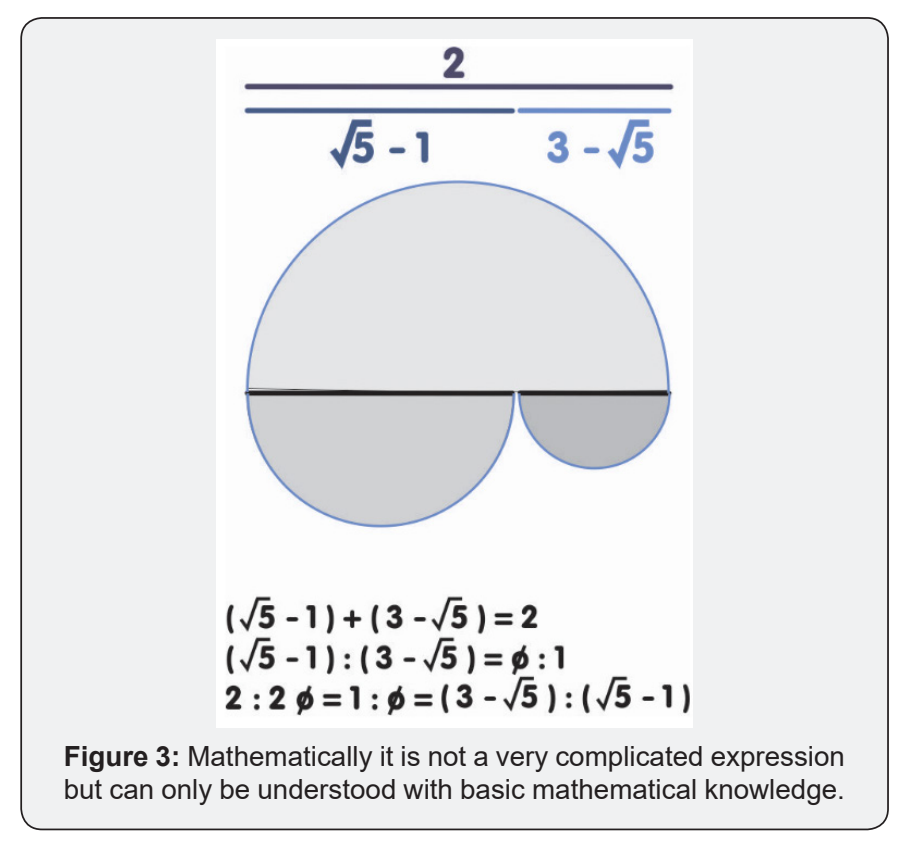

Figure 3: Mathematically it is not a very complicated expression but can only be understood with basic mathematical knowledge.



Figure 4: Human body with some anthropometrical lengths and the golden section, written as mathematical expressions.



Figure 5: The woman's body and the skirt: mini to the end of the hand, midi to the knee and maxi to the ankle (drawing by Marjan Amalietti 1980).

\section{Theory}

Theory is based on mathematical expressions that are certainly exact. This was a problem for masters of vernacular architecture, who had no technical knowledge. Simple geometrical objects helped a lot: the trunk of a tree is circular, but a usable beam must be square - the common relation is the square root of two. Vernacular architecture uses a circle, square and triangle for composing fixed dimensions; in the case of the 
human body it is the golden section. Today we use mathematics, in the past simple but exact geometry was used.

\section{Golden Section}

The golden section is the infinitive proportion of two sides, in which the shorter side is in the same proportion to the longer one as the longer one to the sum of both.

$$
\begin{aligned}
a: b & =b: c \\
c & =a+b
\end{aligned}
$$

Infinitive means that we can prolong this expression

$$
a: b=b: c=c:(a+b)
$$

The diagonal of two squares (the sides of which are equal to one) is equal to $\sqrt{ } 5$.

The whole length is equal to 2 , and the height of the rectangle 1.

The shorter side of the golden section is thus:

$$
\sqrt{ } 5-1
$$

and the longer side:

$$
3-\sqrt{ } 5(\sqrt{ } 5-1)+(3-\sqrt{ } 5)=2
$$

The golden section does not apply only to the human body: the palace of the United Nations Organisation in New York, designed by Le Corbusier, is a very important realisation in golden section. He advocated this proportion in Le Modulor. Further realisations in this mode include Chandigar in India, and a series of buildings in Europe, of which the most important is Unite d'habitation in Marseille [4]. Simplification starts with use of the square root of two: but simple masters did not know theory as we know it today. The trunk of a tree was the basic element in felling timber. It is circular but is primarily used in building in rectangular profiles. The most 'eco' idea is to use the biggest possible rectangular profile from a circle: a square. The relation between the baseline of this square and the diameter of a trunk is:
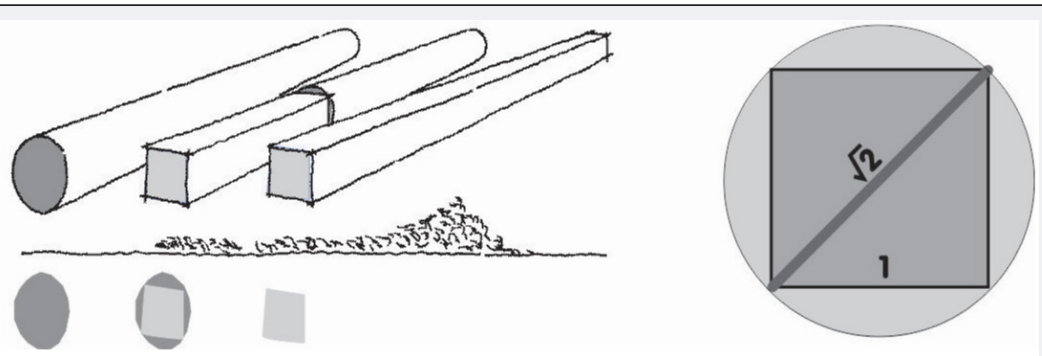

Figure 6: Practice: circular trunk and hewn beam and theory: a square, drawn in the circle.

where the circle's diameter is equal to the diagonal of the square (Figure 6). Practical use can be seen with the most typical Slovene architecture: kozolec or hayrack. This is a stable, vertical, wooden, covered but open object for drying and storing on laths. Historically it was used for drying and storing cereals, today only for hay. It is in use everywhere in Slovenia [5]. John May wrote: 'Dr Borut Juvanec from Ljubljana University has said: It is the only ethnic architecture I know' [6]. The construction of a kozolec/hayrack consists of squares, and its composition is surprisingly exact in all the typical objects (Figure 7).
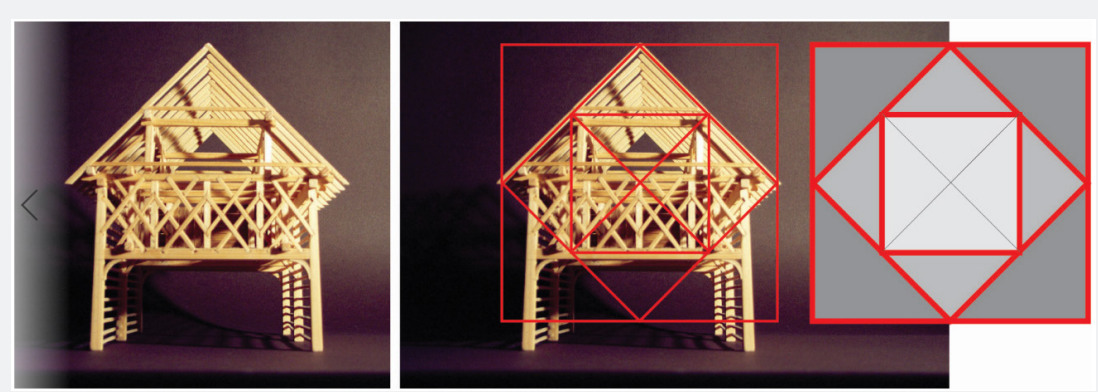

Figure 7: Kozolec / Hayrack shows its composition of squares with the construction of the beams. Squares are drawn in bigger squares The column itself is made of one trunk: in the base it is circular, unhewn, while the upper hewn profile is square.

\section{Symmetry}

The sacred well of Sant'Anastasia in Sardara, Sardinia (Sardegna) is composed of a circular shaft, covered by a false dome. Its diameter is of the same length as the width and length of the construction with staircase.
When drawn, it shows two cubes. Scientific treatment shows the possibility of a sunbeam, reflecting on the water surface and returning to the surface of the earth as 'the beam from inside the Earth'. This is the 'miracle'. It happens every April 21, on the name day of the saint from the nearby church. The name 


\section{Global Journal of Archaeology \& Anthropology}

Anastasia comes from Greek word 'anastasos' which means a sort of resurrection (Figure 8).

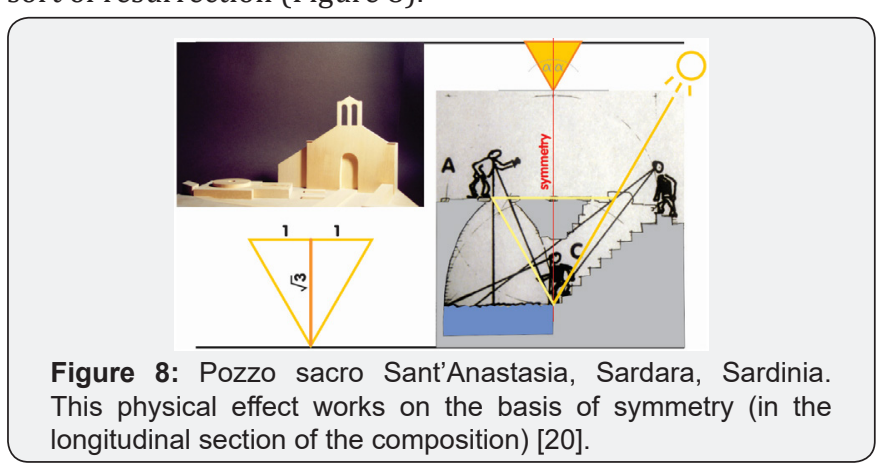

\section{Corbelling and False dome}

The most common composition in drystone is corbelling. This means placing the layers such that each subsequent course overlaps the lower one, right up to the capstone. This can be properly, technically executed only in split stone: the origin is confirmed by the construction of more than six thousand years old tombs. Tombs on the border of Yemen and Saudi Arabia are from the fifth millennium BC, and nawamis from Sinai are from the fourth [7]. The construction is composed of corbelling in cross section and a circle in ground plan. Corbelling is built with the help of the square root of three divided by two (Figure 9).

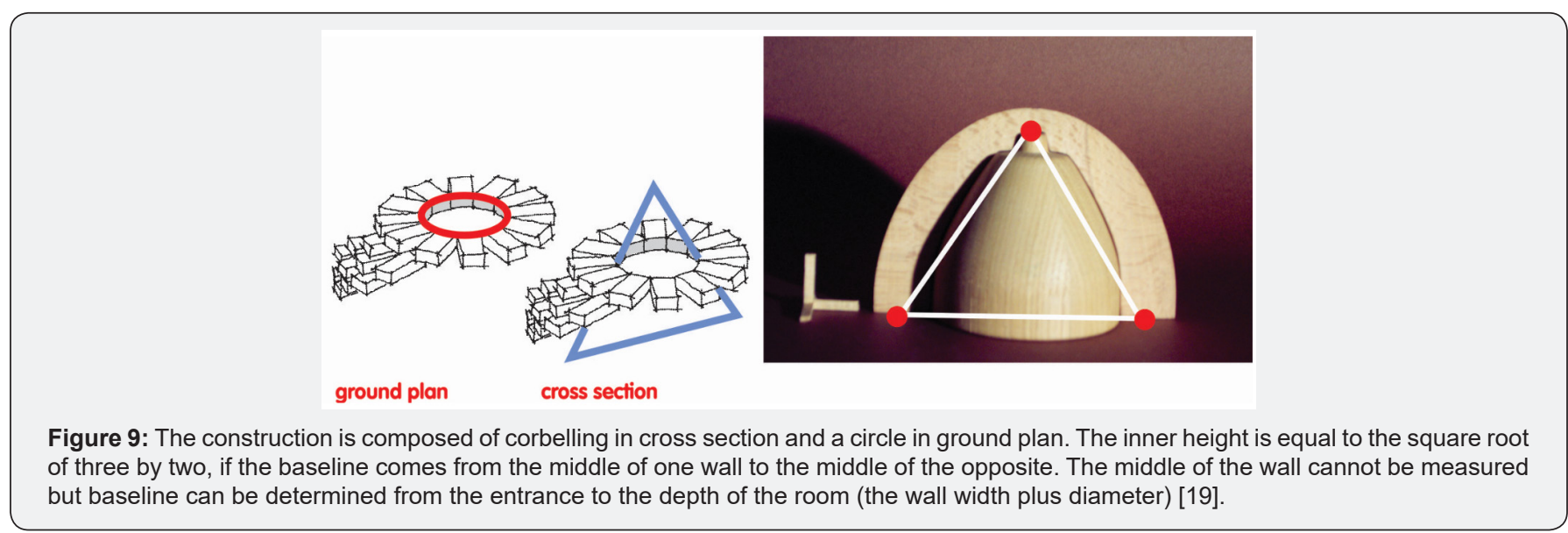

\section{Results}

The result is harmonising interests. The best solution is nature itself: all its elements are built based on the construction, use, function, maintenance, appearance. Only a harmonious composition can be beautiful. Man is part of nature, he cannot be in front of it, only in the first line. It is enough for survival. Man's survival in coarse nature is mostly matter of using the brain. All his works, including in architecture, lead to a better environment, safer and more cultural. Today we call it a 'cultural landscape'. There is no question of whether architecture is more theoretical or more technical: the two elements, hand in hand, compose it. The primeval builder made the first measures himself: with his brain and his body. His thought developed culture and aesthetics in theory, his hands developed certain skills, for practical use. Both brain and hands developed specific methods. Today we hardly believe they existed, but they certainly did. In architectural action or architectural contemplation, people feel pleasure or displeasure; they react [8]. Primeval man understood that order is most important, in his non-consciousness way. Order between quanta: in length or in space (Figure 10).



Figure 10: Theory in practice: realization of the square root of three in a drystone construction. Three sticks can be cut in the bush. The only geometrical element that can be built of three sticks of the same length is an equilateral triangle. Its height is the square root of three by two, if the baseline is one unit long. In a corbelled stone hut the baseline can be used as the depth from the outer wall to the end of the space [17]. 
Prime man formulated the first measures by himself: finger, elbow, foot. The second problem was in the relation of quanta, lengths mostly. Thousands of years before the first theoreticians (Pythagoras, for instance) man used the 'holy triangle' $(3,4,5$ as 'Egyptian') and other physical orders, as well as an equilateral triangle, square, cube etc. The golden section is widely used in detail and in the whole composition. Order helps to co-ordinate complicated elements. Order uses various ways and procedures in settings planned, dedicated to facilitating the work or to making it better. Order means restriction to people of narrow vision. For open-minded people it provides new possibilities. Practice in architectural order is very simple: starting with orientations, planning, designing, building, putting to work. This scheme cannot be changed and none of elements can be neglected. 'An important topic became the quest for potential factors which determine the shape of architectural constructions and which can explain the enormous diversity of house forms' [8]. Today we understand things with knowledge of science (in proportion theory: mathematics, geometry). Yesterday it was harder: Pythagoras knew more about geometry two thousand years and more ago but use of his knowledge until, say 1800 with the introduction of the meter, was limited to some bright people only (Figure 11).

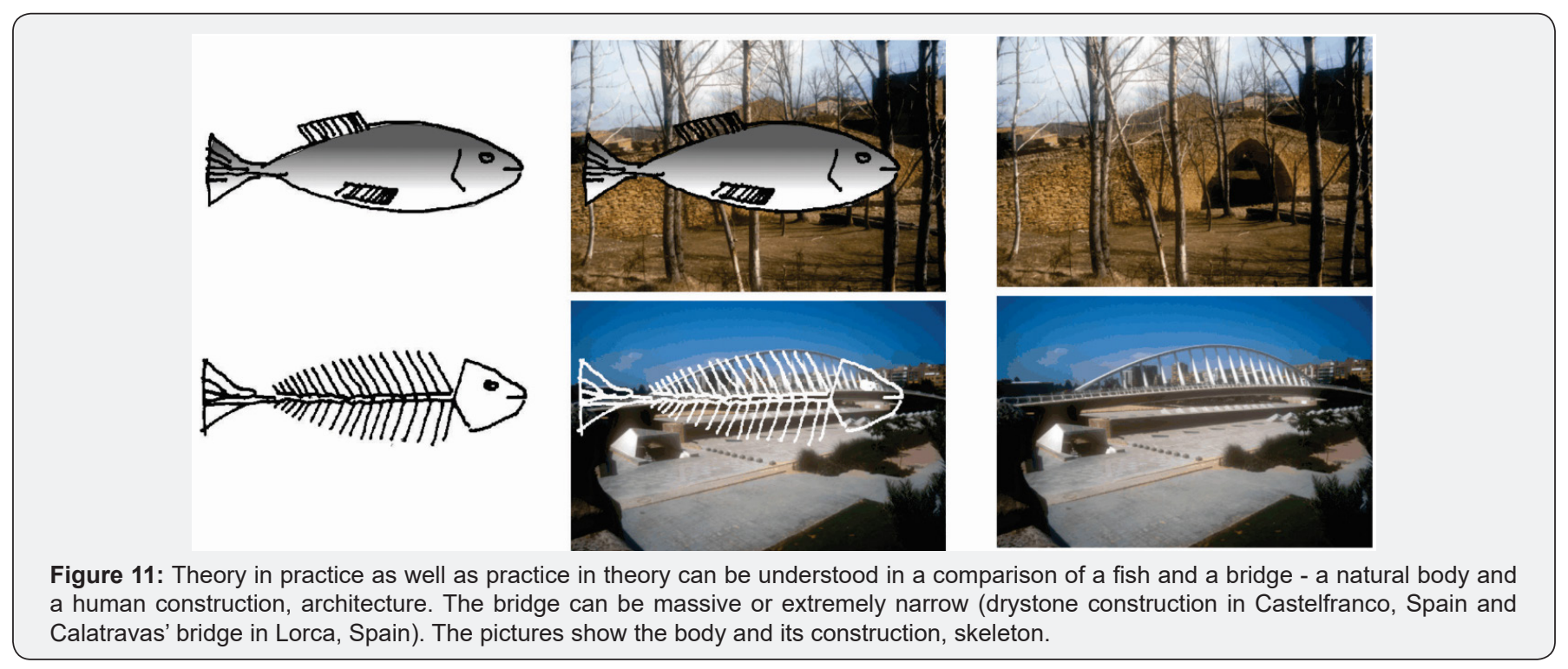

Both compositions work, and the system and appearances of the bridges are totally different. Understanding their constructions is very simple. I have mentioned some theoretical problems, but they must be explained in practical ways, because they represent culture and incredible treasure of the heritage received from our forefathers. A man or a human body is obviously the key. Anthropology, as a scientific study of human beings and their physical, social, material and cultural development [9], and especially anthropometry, are basic elements for scientific treatment. Anthropometry is 'the science of measurements as applied to the physical varieties of man of all times and places. Such characteristics as height and weight, the proportions of the body, the rhythm of growth from before birth until death, are measured with instruments and the results charted in statistical tables for analysis and interpretations' [10-15]. This thought fits directly into architecture, especially vernacular architecture.

\section{Conclusion}

Nature is built in very strict order. Primeval man saw it all in nature: order reigned in nature and what is against order is condemned to collapse. Everything happens according to tradition. Non-functioning in nature means simply the end of an activity [16-23]. Nature is harmonized and man's work in it must be the same. Use of fixed dimensions in selected order means calm composition of harmonious elements. Only a totally harmonious composition can work perfectly and be beautiful. The conclusion is a very short recognition: beauty is the final goal of art - if art is the ultimate conception in our built world, deriving from an architecture.

\section{References}

1. Juvanec B (2009) Basics of Proportion Systems in Architecture, In: Prostor 17, Zagreb, 1: 37.

2. Kurent $\mathrm{T}$ (1973) Preporuka za dimenzioniranje gradjevinskih elemenata, Gospodarska zbornica Slovenije, Ljubljana, Europe.

3. Huber F (2005) Ordo Et Mensura, Landesamt fuer Vermessung, Bayern, Muenchen, Germany.

4. Corbusier Le (1964) Le Modulor, L'Architecture d'Aujourd'hui, Boulogne, France.

5. Juvanec B (2017) Popovo polje, a different View, In: Acta carsologica, Ljubljana, Europe.

6. May J (2010) Buildings without Architects, Rizzoli, New York, USA.

7. Juvanec B (2013) Architecture in Slovenia 5, The Karst, Ljubljana University, i2, Ljubljana, Europe.

8. Oliver P (1997) Encyclopedia of Vernacular Architecture, Cambridge University Press, Cambridge, UK. 
9. Landau S (2000) Webster Contemporary Dictionary, JG Ferguson Publishing Company, Chicago, USA.

10. Stein J (1954) The Everyday Encyclopedia, Random House, New York, USA.

11. Amerlinck MJ (2001) Architectural Anthropology, Bergin \& Garvey, London, UK.

12. Egenter N (1994) Semantic and Symbolic Architecture, Structura Mundi, Lausanne, Switzerland, Europe.

13. Egenter N (2004) Architectural Anthropology, where do the meaning comes. In: AR Architecture Research 2004/1, Ljubljana B Juvanec (Eds.), Europe.

14. Fellner J (2001) Alte Holzregeln, OE Kunstverlag Wien Springer Verlag, Berlin, Germany.

15. Hippel W (1994) Mass und Gewicht in der Bayerischen Pfalz, ILK Mannheim, Germany.

a. Juvanec B (1996) Istarski kažun, In: Prostor, Zagreb, Balkans, Europe, p. 3-96.

b. Juvanec B (2000) Les abris de l'Europe, In: L'Architecture Vernaculaire, Paris, France, xxiv: 62-73.
16. Juvanec B (2000) Six Thousand Years of Corbelling, Icomos/Unesco Millennium Congress, Paris, France.

17. Juvanec B (2005) Kamen Na Kamen, I2, Univerza v Ljubljani Ljubljana, Slovenia, Europe.

18. Juvanec B (2007) Kozolec, Založba I2, Univerza v Ljubljani, Ljubljana, Europe.

19. Juvanec B (2008) Chozo De Extremadura, Joya en Pietra, ARTE Caceres, Europe.

20. Juvanec B (2014) Sacred Well Sant'Anastasia, Sardinia, In: Restauro archaeologico, Firenze, Italy, 1: 78-93.

21. Juvanec B (2019) Slovenia, Architecture, Heritage, i2 and SAZU Ljubljana, Europe.

22. Langhein J (2004) Allgemeine Proportionstheorie in Praxistest, In: Ordo Et Mensura viii, Huber F, Rottlaender R (Eds.), Scripta Mercaturae Verlag, Berlin, Germany.

23. Rapoport A (2001) Architectural Anthropology or EnvironmentBehavior. In: Architectural Anthropology, Amerlinck MJ (Eds.), Bergin \& Garvey, London, UK.

\section{Your next submission with Juniper Publishers} will reach you the below assets

- Quality Editorial service

- Swift Peer Review

- Reprints availability

- E-prints Service

- Manuscript Podcast for convenient understanding

- Global attainment for your research

- Manuscript accessibility in different formats

( Pdf, E-pub, Full Text, Audio)

- Unceasing customer service

Track the below URL for one-step submission https://juniperpublishers.com/online-submission.php 